\title{
Urban Transformation- The Day of the Good Life as a catalyst for an urban change towards sustainability
}

\author{
Davide Brocchi* \\ Transformation activist, publicist, researcher, lecturer, Doctoral student at Heinrich Heine University in \\ Düsseldorf, Germany.
}

*Corresponding Author: Davide Brocchi, Transformation activist, publicist, researcher, lecturer, Doctoral student at Heinrich Heine University in Düsseldorf, Germany.

\begin{abstract}
How can the "Good Life" (Buen Vivir) be promoted in the city? How can urban resilience be strengthened in a time of multiple crises? What does a district look like that will be designed by its own residents? This text examines the potential of an "intentional transformation towards sustainability", which is mainly bottom-up, driven by "unconventional alliances" (including between citizens and institutions) at the local level. The empirical source of knowledge for the analysis is a "real-world lab" in Cologne (Germany). Since 2013, the so-called "Day of the Good Life" (Tag des guten Lebens) takes place once a year. It is supported by a diverse local network of about 130 organizations and many dedicated citizens. This day isn't an event, but serve as a catalyst in a comprehensive process, that promotes trust and cooperation in the neighbourhood and makes a whole district to a commons. This process shows why a transformation towards sustainability isn't first a question of economic capital or of technological innovation, but of human and social relationships.
\end{abstract}

Keywords: commons, good life, Cologne, neighbourhood, sustainability, participation, urban development, real-world lab, city, transformation, sharing culture, co-creation, public-citizen-partnership, empowerment

\section{INTRODUCTION}

Global warming, species extinction, peak oil, volatile economies, social polarization, crisis of democracy... There is actually no doubt, that a radical change is imminent, we are probably already in the midst of it. The only question is, whether it will take place: by design or by disaster (cf. Sommer / Welzer 2014: 26). If the German Advisory Council on Global Change (WBGU, Wissenschaftlicher Beirat der Bundesregierung Globale Umweltveränderungen) calls for "a social Contract for the Great Transformation" (WBGU 2011), then it pleads unequivocally for a Transformation by design. It is about an intentional transition of the global society to sustainability (cf. Grießhammer / Brohmannder 2015: 6), whereby the concept of sustainability can be defined negatively and positively (cf. Brocchi 2014: 60):

- Sustainability is the counter model to any development that leads social systems into an evolutionary impasse (cf. Diamond 2005). It is therefore a necessity.

- Sustainability stands for a development that enables a good life for as many people as possible (cf. Schneidewind / Zahrnt 2013; Acosta 2013). It is therefore an opportunity.

But where can the Great Transformation best begin today? So far, the sustainability process has been driven forward like the process of globalization: above all centralistically, from the global to the local, top-down. However, this form of governance is not only part of the solution, but also part of the problem. Just as neoliberal globalization has ultimately led to a devastating financial crisis, just as there is a growing divergence between the declared sustainability goals and the real societal development at key indicators like the global CO2-emissions (cf. Welzer / Wiegandt 2011: 7). The international sustainability process is hardly progressing. Therefore, a change in the German-speaking transformational debate has taken place in recent years. The focus is now on polycentric approaches (cf. WBGU 2016: 4), bottom-up strategies that focus on transformation from the local to the global. They form the starting point of this essay. Using the concrete case study, it explores the question of how the transformation toward sustainability is initiated and shaped participatively by the citizens 
themselves, in the local. The WBGU formulates this question as follows: "How can people influence dynamic urbanization processes or participate in them, when many urban areas are passing through profound changes or are being built completely from scratch in a short period of time?" (WBGU 2016: 7).

Cities are trouble spots and at the same time pioneers of change. That is why they represent one of the 17 new Sustainable Development Goals (SDGs) adopted by the United Nations in September 2015. The mission of the SDG 11 is to "make cities and human settlements inclusive, safe, resilient and sustainable" (UN 2015). Today, the largest part of humanity lives in the cities, and by 2050, it could become two-thirds of them (cf. WBGU 2016: 1). For this reason, the future of the entire world society could decide on the question of how cities develop; whether the natural foundations of life are preserved and the planetary limits of load capacity are adhered to. Especially cities of industrialized countries like Germany have a high global responsibility. Here the resource and energy consumption, the CO2-emission or the produced waste are particularly high. Their lifestyle has profound implications for developing and emerging economies, which often serve as suppliers of raw materials and food, landfills or low-cost labor camps, while being hit hardest by climate change (cf. Lessenich 2017). A structural asymmetry in the global society ensures that ever larger masses of war and climate refugees, asylum seekers and migrants are wandering into the "prosperity islands", whereby social polarization and conflicts crystallize in the cities.

But the very fact that cities are a spatial concentrate of human diversity, creativity and knowledge is their great potential for transformation. It can be best developed through the formation of unconventional alliances, by building new "bridges" and breaking down visible and invisible walls. The scandals surrounding the large-scale projects of recent years in German cities (the collapse of the Historical City Archive in Cologne by the construction of a new subway line; the never ending construction of the new Berlin-Brandenburg Airport, ecc.) have shown that a top-down governance cannot even work on the local level and a decentralized governance is also useful at this level. Therefore, this essay recognizes the greatest potential for transformation in the neighbourhood. Neighbourhoods are ideal "urban laboratories" (cf. Schneidewind 2014) for learning transformation on a smaller scale; to initiate, experiment and advance transformational processes that can then be transferred to the whole city. "An urban transformation towards sustainability can only be realized through small-scale territorial units formally integrated into the political decision-making process, such as neighbourhoods" (Bachmann / Behrens et al. 2017: 1). ${ }^{1}$

How can the "Great Transformation" concretely starts in the neighbourhoods of cities and be supported by unconventional alliances and the citizens themselves? This essay describes the approach behind a successful initiative: Day of the Good Life, Tag des guten Lebens in German. Since 2013 it takes place once a year in a different district of Cologne. This day, which is subtitled "Cologne Sunday of sustainability", is not just another event for citizens to enjoy for the day before going back to their normal lives; it should serve as a "catalyst for a transformation of the city towards sustainability and post-fossil society" (Brocchi 2012: 27).

The potential of the initiative has been demonstrated by the mass of activated citizens in the city as well as through national recognition after the success in Cologne.

The next paragraph will describe the approach and the process of transformation behind the Day of the Good Life in Cologne. It will be discussed in the following paragraph, before the conclusions.

Methodically, the empirical case is considered here from the perspective of the observer and the codesigner (cf. Schneidewind 2014: 3), because the author himself was the project initiator, idea developer and significantly involved in the process for three years. This is a contribution in the sense of a transformative science, that is "science that acts as a catalyst for societal change processes" (Schneidewind / Singer-Brodowski 2014: 69).

\section{The Day of the Good Life in Cologne}

What would our cities look like if they were designed and governed bottom-up, by the citizens

\footnotetext{
${ }^{1}$ All the German quotations in this essay are translated by the author himself.
} 
themselves, as commons? If such an idea does not reflect the reality of an entire city 365 days a year, then we could start with one day a year in one neighbourhood. This is the core of the approach to transformation behind the Day of the Good Life.

Cologne is the first 'real-world lab' where this approach has been successfully tested and developed. In 2011 the concept of introducing a 'Sunday of Sustainability' in this city was honoured with a local award (Dialog Kölner Klimawandel) for innovative project ideas aimed at climate protection in the city. To bring the idea to life, a diverse local network was founded. Nearly 130 organizations, cultural institutions, schools, initiatives and companies (among others) and many committed citizens have signed up to the Agora Köln (Agora Cologne). The platform's name describes its purpose: in the ancient Greek polis, the agora was the public meeting place where direct democracy emerged. Citizens met there to collectively determine how to develop their own city. Likewise, the Agora Köln pursues the goal of urban development from the bottom up, through unconventional alliances for sustainability between actors from different sectors (environmental, economic, social and cultural) and between neighbourhoods, civil organisations and local institutions.

But where is the agora in the modern city? Unfortunately, public space is increasingly occupied by traffic and commercial activity, where people take on the role of motorists and consumers; accordingly, political and economic institutions follow suit, designing spaces that are well suited to motorists and consumers. Urban open spaces in which one can be a citizen (a political subject instead of an object) become increasingly scarce. The Agora Köln is also campaigning for a "right to the city" (Lefebvre 1968; Harvey 2013), more precisely, for everyone's right to a viable and liveable city. On the Day of the Good Life, the network together with the neighbourhoods transforms the space for traffic and consumption into an open agora. This transformation is made possible by a corresponding (and so far unanimous) decision made by the neighbourhood's representative assembly. The Day of the Good Life shows the transformative potential of public-citizen-partnerships instead of publicprivate-partnerships. As many streets and squares as possible are then closed off to motorized traffic and in some cases completely free of parked cars. The space becomes a large open-air public stage, where community members can socialise and implement their own concepts of the 'good life'. The condition is that all action must be non-commercial: nothing can be sold or bought, only donated or shared. The euro gets replaced by a new currency, so to speak, that of trust, for one day in that neighbourhood. The sphere of the "gift economy" (Mauss 2016) expands from the familiar circle to include the neighbourhood. In the family, trust and a sense of community need two main ingredients:

(a) Space as a commons. Where would family as such take place if there weren't a dining or living room? The good life needs such common rooms in every street as part of the infrastructure of sustainable cities. Commons don't exist; they are made (Helfrich 2011). Private spaces can also be transformed into a commons. Physical spaces as commons can be the "totem" (Durkheim 1902) that symbolize and promote identification with an inclusive community, beyond differences among classes, milieus or generations. This emotional identification is stronger when the common space is self-made, designed and furnished in a participative way, with simple materials. Through the 'our' (our neighbourhood, our street, our living room) everybody senses and exercises the right to participate, to be involved. The commons and the community cause and presuppose each other.

(b) Common rituals. In a family, people meet at the same time in the same space with an informal or formal motive: dinner, Christmas, to discuss a problem, find a common solution and redefine the rules of living together. What would homemade rituals for the neighbourhood look like? The Day of the Good Life offers a frame for the collective creativity at the local level, for combining best practices (for example, international Restaurant Day, PARK(ing) Day, theatre in living rooms, repair cafés...). The name of this ritual, the good life, is in line, for example, with the buen vivir debate in Latin America (Acosta 2013) on alternative "welfare models" to replace the dominant model centred on economic growth and consumerism (cf. Sachs 2010). On the Day of the Good Life, the global learning perspective is reversed: during the transition from colonisation to globalisation, the Western 'advanced modern culture' told 'underdeveloped traditional cultures' how they should live. But on the Day of the Good Life, each neighbourhood can ask a new question: What can we learn from other (sub) cultures, for example, about a life that is more in tune with nature, in equilibrium? We don't need to take long flights to explore diversity: The Day of the Good Life wants to make the diversity that is already present nearby (migrants, homeless people, bank managers...) and in ourselves more visible and promote a dialogue with it. 
Every Day of the Good Life is a step towards the sustainable transformation of the city. The introduction of the Day itself was only the first step; every following year, the steps towards transformation should build on that. Since 2013, the Tag des guten Lebens takes place once a year in a different neighbourhood of Cologne: 2013 and 2014 in Ehrenfeld, 2015 in Sülz, 2017 in Deutz and this year's 2018 in Agnesviertel/Eigelstein. Each of these areas $\left(1-2 \mathrm{~km}^{2}, 20,000-30,000\right.$ inhabitants, 25-35 streets) went car-free and were remodelled by civil society and local residents for one Sunday.

For each of the neighbourhoods, all of the residents were invited several months beforehand by the Agora Köln to a community conference, where the offer to govern the district for one day from the bottom up was presented. In this meeting, the residents were subdivided into street communities to coordinate themselves. The principle is that small groups and spaces better correspond to the human scale than bigger ones. Every street community met autonomously in the following months and discussed various questions: What are some ideas for better living on our street? How would we live together? Which kind of mobility do we want in our neighbourhood? How do we want to promote solidarity and stop gentrification? On the Day of the Good Life, every street community has the chance to take the results of their own discussions on the good life in the open space of the street and turn them into a reality. Here the transformation isn't reduced to a dialogical process or a process of enlightenment, dominated by people with an academic background (who can better deal with verbal communication and rational knowledge). The nonverbal communication of shaping and acting together is much more inclusive, because it touches the deeper feelings and emotions of everybody, not only the conscious factors (s. iceberg model of the psychology) (cf. Ruch/Zimbardo 1973; Watzlawick 2007: 53-54).

In this process, as much responsibility as possible is transferred to local residents. The Day of the Good Life is a social sculpture, in that the city is shaped by a collective creativity in a self-determined way. Every citizen becomes an artist (Beuys 1978). The first commons intervention takes place the day before when everybody parks their car further away, dramatically changing what the neighbourhood looks like. People experience self-efficacy, where with just one small action, they can make a radical impact on their neighbourhood. What would the city look like without cars? Every citizen makes or experiences sustainability at their own front door. It is much more convincingly than hearing about it. "Self-made", it promotes a deeper emotional motivation and identification than heteronomy. It is interesting to see that the most typical action neighbourhoods take on the Day of the Good Life is to transform the street into a common dining and living room; people order their private tables, chairs and couches together in a public space.

A self-made dining and living room in the neighbourhood (Day of the Good Life 2013, Cologne).

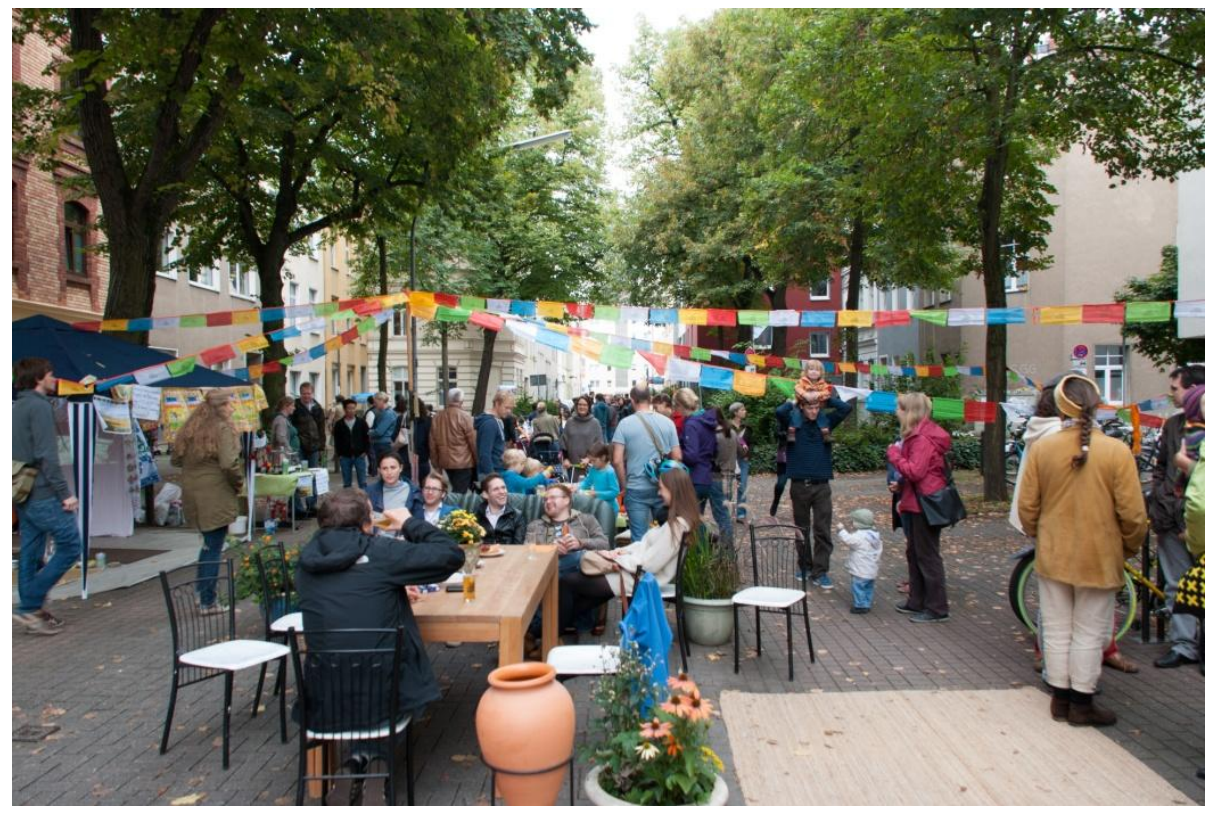

Photo: Marén Wirths

The inhabitants transfer unconsciously and spontaneously a familiar strategy on the neighbourhood, for expanding the circle of trust and of the "gift economy". Anonymity is so partially reduced; people 
who for many years lived side by side without knowing each other meet here for the first time. A woman, resident of Ehrenfeld, said to me once: "Since the Day of the Good Life, I need an extra 15 minutes every morning when going to the bakery, because I get stopped by people I never knew before." (quoted in Brocchi 2017: 119)

The Day of the Good Life serves first as a catalyst for social interaction in the neighbourhood. On the one hand, the residents meet regularly in advance to design and organize the program for the day in their own neighbourhood or on their own street. On the other hand, the day itself creates open space in the form of car-free squares and streets, where social interaction takes place and is promoted through joint action (e.g. breakfast outdoors with neighbours). For its part, social interaction generates trust, and this plays a key role in transformation processes towards sustainability for several reasons:

a) For the system theorist Niklas Luhmann (1989: 8) trust is "an effective way of reducing complexity (both objectively and subjectively)". Trust activates shared resources and thereby reduces the paralyzing feeling of powerlessness. Studies confirm that people's well-being is most pronounced where, in addition to a healthy environment, there is also a climate of trust that allows for the coexistence of social cohesion and individual self-determination.

b) Trust is an important prerequisite for people's willingness to share - not just cars, books and tools but also community responsibility. In a context of trust, lifestyles become less material: what is shared does not have to be bought or, thus, produced. Relationships replace materiality. Social capital makes transformation possible where economic capital is scarce. This strategy widens the creative scope for highly indebted cities such as Cologne.

c) In an atmosphere of trust, people prefer to be part of a community than to show off their social status. If it's true that social status is exhibited through our habitus and the way we consume (Bourdieu 1984), then a trustful atmosphere changes, for example, our mobility behaviour: People move from A to B by bicycle instead of a big SUV (sport utility vehicle). Cities like Copenhagen or Amsterdam aren't only characterized by more sustainable forms of mobility but also by more trustful relationships among citizens as well as between civil society and institutions.

d) For the political scientist and winner of the Nobel Prize in Economics Elinor Ostrom (1990), commons are sustainably managed where the users cooperate with each other. "People tend to overuse common resources, if they do not know each other. In contrast, groups that communicate regularly with each other are able to achieve almost optimal results in resource management. The dilemma can be avoided by building trust. It is the most difficult but most reliable way to ensure that one's own limitation is rewarded by the other" (Helfrich, Kuhlen, Sachs et al., 2009: 30). With the Day of the Good Life, the city is transformed into a commons, and each neighbourhood and each street are considered as commons and treated by their users accordingly responsibly.

The promotion of neighbourhood and democracy is the constant in the transformation behind the Day of the Good Life as a process. This process is made progressive by annually rotating what neighbourhood the Day of the Good Life takes place in and what that year's main issue focuses on. This main issue is defined by the Agora Köln together with the neighbourhoods and corresponds to whatever those citizens are worried about, turning into a new common step towards the transformation of the city. In line with the launch of the first Day of the Good Life, the main issue in 2013 in Cologne was sustainable mobility, against the extremely car-friendly politics of recent decades. The 130 organisations behind the Agora Köln defined a common alternative mobility programme for the city (Agora Köln 2015), and the Day of the Good Life served as a high point in a city-wide campaign for a change in mobility. While the secondary streets were governed by the respective street communities, Ehrenfeld's main traffic road was reserved for a central programme focussed on the main issue. Related organisations showed how sustainable mobility can work. Because the visitors from outside were concentred here, the secondary streets offered a more protected space for the neighbourhoods. Every Day of the Good Life is the biggest car-free day in Cologne since the 1970s, and to facilitate the absence of the car on the Day of the Good Life, public transport throughout Cologne should be free, as per the original plan (Brocchi 2012: 4, 29). The Cologne City Council voted in March 2016, by a large majority, for a day without tickets from the city's transport companies. 
To address diversity in civil society and promote a multi-dimensional urban development, the issue that shapes the transformation steps changes each year, rotating between ecology, economics, society and culture. The main issue for the Agora Köln 2014 and 2015 was free spaces and common spaces in the city and in 2018, sustainable nutrition. The rotating of issues is very important for attracting different milieus and interest groups. Diversity begets diversity.

Through the Day of the Good Life, every single step of transformation becomes the focus of public and media attention, which in turn boosts its implementation. The yearly rotating of neighbourhoods and main issues allow the Agora Köln (as a local movement for a progressive transformation of the city) to grow constantly, by networking with a new neighbourhood, milieus and stakeholders. When enough neighbourhoods are mobilized, the Day of the Good Life could take place throughout the whole city, so that there are no more 'producers of the good life' (the residents of the car-free neighbourhood) and 'consumers of the good life' (the visitors from outside), 'but only prosumers of the good life' throughout the whole city.

The Day of the Good Life continues to be a flagship project. In 2017, it won the first German Neighbourhood Award from the Foundation nebenan.de, out of 1,300 candidates. Alberto Acosta, one of the main speakers in the Latin American debate on buen vivir, supports the idea of an international Day of the Good Life. Local initiatives from different German cities are now networked for drafting a common manifesto for a German Day of the Good Life and setting a common date. The city of Dresden is planning a Week of the Good Life for May 2020, and the Day of the Good Life could take place in three different districts of Berlin. In the German capital, the first main issue will be the current biggest problem for disadvantaged people and subcultural initiatives there: the soil and the housing policy. To whom does the city belong, its citizens or the real estate investors?

\section{DISCUSSION}

There are no patent remedies for the great transformation, and not just because cities and neighbourhoods can differ greatly. First, as the ecosystems with the higher biodiversity are more resilient, as cultural diversity makes a social system more resilient. Sustainability cannot be a universal patent remedy, because it is a program of diversity, opposite to the monocultural top-down program of the modernisation and globalisation. Second, the great transformation towards sustainability happens in a area of tension, that concerns especially the question of how there can be a right life in the wrong one (cf. Adorno 2006). How can people create real alternatives, even though they are part of that society and carry that culture in themselves, that needs to be changed? How can people, who are everyday educated to consume more or to compete, begin to share and to cooperate with each other?

Transformation processes take place in areas of tension marked by ambivalences and contradictions. Especially against this background, the potential of initiatives like the Day of the Good Life as urban "real-world lab" come into play: here, the learning process, that the great transformation needs, can be unfold.

What can we learn about transformation processes from the Day of the Good Life in Cologne?

Here some findings:

a) Not only the culture of the modernisation is characterised by myths (progress, economic growth, free competition...), but also some cultures of sustainability. There democracy, community or neighbourhood are idealized. Such idealizations are on one hand a source of personal motivation in supporting the transformation, but they create also false expectations and can lead very quickly to delusions in the praxis. On the other hand an idealization means a mental hierarchy: the simply idea is superordinated to a much more complex reality. Here transformation means to shape the reality into the narrow form of an harmonic idea; to manage the process as a platonic "demiurge". Good life means the opposite: more emancipation, more self-determination, than heteronomy. Community, neighbourhood or trust cannot be prescribed or planed from the top. Empathy means a sensibility for the inner reality of other humans, that is not less diverse and contradictory as our own. A new relationship needs openness on both sides; an openness to the "stranger" and to an "incalculable liveliness", that can leads also to conflicts instead of harmonies. Conflicts are normal especially in symmetric relationships; the more important question is how to deal with them. Cooperation isn't a 
goal, but the capacity to organize contradictions in the everyday life.

The Day of the Good Life creates in the middle of the city an experimental space for developing new forms of democracy and of cosmopolitan community. This initiative is not about simply transferring the collectivistic village community into the city, it is not longing for traditional forms of homeland. Here individuality and community or otherness and commonality are placed in a new relationship. On one hand such initiatives want to be an integrating moment for different people in the neighbourhoods ('home is where, I can shape with'), on the other hand, the high mobility in the local population of a modern city creates a bridge between locality and globality, with impulses and knowledge constantly inward and outward be transmitted outside. The migrants and the refugees are ambassadors of other realities in the neighbourhood.

b) The actual digitalization of the social communication offers new chances also for the transformation in the neighbourhood. It makes possible to reach people behind their doors and to create new connections. This form of communication is very cheap and easy in an high technologized society like Germany. Marshall McLuhan described technologies as "body prosthesis", because every technology aims to strengthen an ability (cf. McLuhan 1964). But every "prosthesis" is at the same time an "amputation", and it means the loss of a special knowledge and ability. The modern man communicates in the virtual communities with a lot of strangers, but is he able to meet and speak with the own neighbour next door as well?

Not every technological innovation is more sustainable than an old one. The Day of the Good Life is a self-made street school on face-to-face communication in the digitalized society. Face-to-face communication is less manipulable and controllable than the technological one; it is an hot medium (ebd.), because it happens with more senses and needs an higher grad of participation.

c) In bottom-up strategies of sustainability there is a contradictory area of tension between the prescription of normative objectives (climate protection, sustainable mobility, against commercialization of urban areas...) and the possibility of self-development, co-creation and empowerment. Here, initiatives like the Day of the Good Life are concerned with defining the outermost normative orientation framework, in such the residents in the neighbourhood find the greatest possible space for self-development and co-creation. This outermost framework of orientation can on the one hand enable the freedom for co-creation by citizens (for example, as a guarantor of a certain self-administration of the neighbourhood under the condition that processes are democratic and as inclusive as possible) and, on the other, facilitate processes of socialization by preventing pure arbitrariness. A certain reduction of social complexity is necessary to avoid the danger of overtaxing for individuals, who participate voluntarily.

But especially the approaches of commons open scopes for linking the normative principle of sustainability with the possibility of self-administration and empowerment. At the Day of Good Life sustainability begins by changing the perception of the urban space ("our street", "our district") as well as the relationships between the users of this commons. Sustainability must not be prescribed from the top, if the users cooperate with each other in a space and community, that corresponds to the human scale.

d) The Day of the Good Life is expression of an avant-garde, that creates free spaces for the creative evolvement of alternatives to the dominant development model. At the same time it pretends to work in an inclusive way; it is addressed to the diversity; it is aimed to activate and to link the diversity in the neighbourhood. How to deal with such contradiction? For example thinking about a „flat-sharing community". Also a neighbourhood can be understood and managed like a „flat-sharing community“, where rooms of plurality (of individualities, interests, possibilities...) exists besides common rooms of inclusions and consensus. A good life isn't for everybody the same: car drivers and children have different ideas about how to use the street. The Day of the Good Life is connected with the question, how different ideas of good life can coexist or even nourish each other in a neighbourhood. Democracy and coexistence wants to be already learned in a neighbourhood.

e) Social capital is the most important resource and the most important product of the process behind the Day of the Good Life. It takes place because many citizens voluntarily take on and share large and small tasks, replacing the often lacking economic capital. This social capital remains beyond the Day 
of the Good Life and makes the neighbourhood more resilient. This experience shows that the great transformation isn't only possible by a lack of money: It is a chance for strong indebted cities like Cologne too.

The coexistence of social capital and economic capital is one of most important area of tension in the great transformation. As soon as it comes into play, the money has a strong impact not only on the structures of our society, but also on the structures and development of such bottom-up initiatives. The motivation of the participants can change; a professionalization of the structures can be at the expense of participation. In the great transformation, the relationship between social capital and economic capital must be rethought and balanced - and this already within such initiatives. The central precondition for a coexistence of social and economic capital is transparency, fairness and equity.

\section{CONCLUSION}

On the basis of a concrete case study, this essay examined the question of how the transformation towards sustainability can be shaped participatively, by the citizens themselves, in the own neighbourhood. Neighborhoods are suitable places and drivers of the great transformation, for example because they correspond to the human scale and house those niches, that are so important for experiment and developing that solutions, that a transformation by design needs. On the level of neighbourhoods every citizen is an expert.

The transformation towards sustainability needs a systemic approach. The Day of the Good Life aims to combine ecological, economic, social and cultural concerns. This integrative approach is also reflected in the formation of unconventional alliances, not only between actors from different sectors (environmental initiatives, local businesses, social and cultural institutions ...), but also between organized civil society, local residents and parts of institutions. While organizations that operate in wide spaces (nation, European Union, worldwide) often specialize in subject matter in order to remain able to act, local initiatives like the Agora Köln attempts to take a holistic view of the great transformation, but remain capable of action, by reducing the complexity spatially instead of thematically.

Many of the problems to be overcome by the great transformation are problems of democracy - and require a solution at this level. It is the particular relevance and the particular approach of the initiative explored here. While authoritarian developments and xenophobic movements are a negative reaction to the actual crisis of democracy, local civic initiatives could become the seed of a broad movement of strong democracy. But as the crisis of democracy is also the product of an urban development that weaken the commonwealth, as a strong democracy and social capital needs an urban planning conscious of the importance of common self-governed spaces in the neighbourhoods. Their usability should be independent from weather conditions.

If the financial crisis and the crisis of democracy are trust crises, then democracy and the market should be re-founded in a more sustainable way there, where trust can emerge again, where people can interact in everyday life in person, namely at the local level. Where producers and consumers know each other personally, abuse is unusual; advertisement isn't needed to artificially replace the missing trust. Also the success of the Day of the Good Life in Cologne shows, that to give more responsibility and freedom to citizens does not necessirly lead our society to more chaos. Instead it could be an important precondition for a more sustainable welfare and development.

\section{REFERENCES}

[1] Acosta, Alberto (2013): El Buen Vivir. Sumak Kawsay, una oportunidad para imaginar otros mundo. Barcelona: Icaria.

[2] Adorno, Theodor W. (2006): Minima Moralia: Reflections from Damaged Life: Reflections on a Damaged Life. New York: Verso.

[3] Agora Köln (2015): Verkehr des guten Lebens. Ein nachhaltiges Mobilitätskonzept für Köln. Cologne: Agora Köln. http://www.agorakoeln.de/wp-content/uploads/2015/11/AgoraKoeln_Verkehr-des-gutenLebens_Lang_BF.pdf (accessed on: 04.08.2018).

[4] Bachmann, Boris/Behrens, Maria/Brocchi, Davide/Heynkes, Jörg/Sinn, Matthias/Thiesen, Andreas (2017): Subsidiarität als Motor urbaner Transformation. Impulspapier der Themengruppe Partizipation, Demokratie und Gerechtigkeit im Rahmen der Bergischen Klimagespräche 2017. Wuppertal: Wuppertal Institut, http://spiekerooger-klimagespraeche.de/sites/default/files/Bergischer_Impuls_01_0.pdf (Zugriff: 
17. Jan. 2018).

[5] Beuys, Joseph (1978): Jeder Mensch ein Künstler: auf dem Weg zur Freiheitsgestalt des sozialen Organismus. Achberg: FIU-Verlag.

[6] Bourdieu, Pierre (1984): Distinction: A Social Critique of the Judgement of Taste. London: Routledge.

[7] Brocchi, Davide (2017): Urbane Transformation. Zum guten Leben in der eigenen Stadt. Bad Homburg: VAS.

[8] Brocchi, Davide (2014): Das (nicht) nachhaltige Design. In: Fuhs, Simone/Brocchi, Davide/Draser, Bernd/Maxein, Michael (Hrsg.): Die Geschichte des Nachhaltigen Designs. Bad Homburg: VAS, S. 5480 .

[9] Brocchi, Davide (2012): Ideen für eine zukunftsfähige Stadt. Der Tag des guten Lebens: Kölner Sonntag der Nachhaltigkeit. Cologne: Eigenverlag. http://davidebrocchi.eu/wp-content/uploads/2013/08/2012_ koelner_Sonntag_der_nachhaltigkeit.pdf (accessed on: 04.08.2018).

[10] Diamond, Jared (2005): Collapse: How Societies Choose to Fail or Succeed. London: Penguin Books.

[11] Durkheim, Émile (1902): Sur le totémisme. In: L’Année Sociologique 5/1902, S. 82-121, http://classiques.uqac.ca/classiques/Durkheim_emile/annee_sociologique/an_socio_4/totemisme.html (accessed on: 25.01.2018).

[12] Harvey, David (2013): Rebel Cities: From the Right to the City to the Urban Revolution. New York: Verso Books.

[13] Helfrich, Silke (2011): Gemeingüter sind nicht, sie werden gemacht. In: Was mehr wird, wenn wir teilen, E. Ostrom, 11-19. Munich: oekom.

[14] Helfrich, Silke; Kuhlen, Rainer; Sachs, Wolfgang et al. (2009): Gemeingüter - Wohlstand durch Teilen. Berlin: Heinrich Böll Stiftung.

[15] Grießhammer, Rainer/Brohmannder, Bettina (2015): Wie Transformationen und gesellschaftliche Innovationen gelingen können. Dessau: Umweltbundesamt. https://www.umweltbundesamt.de/sites/ default/files/medien/376/publikationen/wie_transformationen_und_gesellschaftliche_innovationen_geling en_koennen.pdf (accessed on: 26.08.2018).

[16] Lefebvre, Henri (1968): Le Droit à la ville. Paris: Anthropos.

[17] Lessenich, Stephan (2017): Neben uns die Sintflut. Die Externalisierungsgesellschaft und ihr Preis. Berlin: Hanser.

[18] Luhmann, Niklas (1989): Vertrauen. Ein Mechanismus der Reduktion von Komplexität. Stuttgart: Enke.

[19] Mauss, Marcel (2016): The Gift. London: Hau.

[20] McLuhan, Marshall (1964): Understanding Media. The Extensions of Man, New York: McGraw-Hill.

[21] Ostrom, Elinor (1990): Governing the Commons: The Evolution of Institutions for Collective Action. Cambridge: Cambridge University Press.

[22] Ruch, Floyd L./Zimbardo, Philip G. (1973): Psychology and Life. Glenview: Scott Foresman.

[23] Sachs, Wolfgang (ed.) (2010): The Development Dictionary: A Guide to Knowledge as Power. London: Zed Books.

[24] Schneidewind, Uwe; Singer-Brodowski, Mandy (2014): Transformative Wissenschaft. Marburg: Metropolis.

[25] Schneidewind, Uwe (2014): Urbane Reallabore - ein Blick in die aktuelle Forschungswerkstatt. pndonline, III/2014. Aachen: RWTH, http://www.planung-neu-denken.de/images/stories/pnd/dokumente/ 3_2014/schneidewind.pdf (accessed on: 17.02.2018).

[26] Schneidewind, Uwe/Zahrnt, Angelika (2013): Damit gutes Leben einfacher wird. Perspektiven einer Suffizienzpolitik. Munich: Oekom.

[27] Sommer, Bernd/Welzer, Harald (2014): Transformationsdesign. Wege in eine zukunftsfähige Moderne. Munich: oekom.

[28] UN (2015): Transforming our world: the 2030 Agenda for Sustainable Development. New York: United Nations. https://sustainabledevelopment.un.org/post2015/transformingourworld (accessed on: 26.08.2018).

[29] Watzlawick, Paul (2007): Menschliche Kommunikation. Formen, Störungen, Paradoxien, Bern: Hans Huber.

[30] WBGU - Wissenschaftlicher Beirat der Bundesregierung Globale Umweltveränderungen (2016): Humanity on the move: Unlocking the transformative power of cities. Berlin: WBGU. https:// www.wbgu.de/fileadmin/user_upload/wbgu.de/templates/dateien/veroeffentlichungen/hauptgutachten/hg2 016/hg2016_en.pdf (accessed on: 26.08.2018). 
[31] WBGU - Wissenschaftlicher Beirat der Bundesregierung Globale Umweltveränderungen (2011): World in Transition - A Social Contract for Sustainability. Berlin: WBGU. https://www.wbgu.de/fileadmin/ user_upload/wbgu.de/templates/dateien/veroeffentlichungen/hauptgutachten/jg2011/wbgu_jg2011_en.pdf (accessed on: 26.08.2018).

[32] Welzer, Harald/Wiegandt, Klaus (Hrsg.) (2011): Perspektiven einer nachhaltigen Entwicklung. Frankfurt/ Main: S. Fischer.

\section{AUTHOR'S BIOGRAPHY}

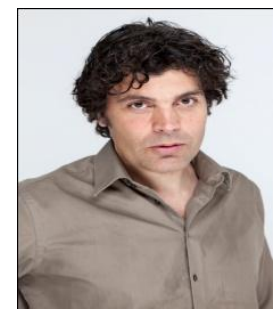

Davide Brocchi, born in 1969 in Rimini, Italy, moved to Germany in 1992 and lives in Cologne. The graduate social scientist works as a transformation activist, publicist, researcher, and lecturer. His work focuses on the cultural dimension of sustainability, the formation of unconventional alliances and urban transformation as a participatory process. Among other things, he initiated the Festival of Cultures for another World (2003, Düsseldorf), the nationwide networks Kulturattac (2003) and Cultura21 (2005), the Alliance Agora Cologne and the annual Day of the Good Life: Cologne Sunday of Sustainability (2012). In 2017 he published the book Urbane Transformation. Zum guten Leben in der eigenen Stadt (Urban Transformation: Towards a Good Life in Your Own City). In addition to social sciences, he studied politics, psychology and philosophy, among others with Professor Umberto Eco at the University of Bologna. For further information: http://davidebrocchi.eu

Citation: Davide Brocchi. "Urban Transformation- The Day of the Good Life as a catalyst for an urban change towards sustainability" International Journal of Humanities Social Sciences and Education (IJHSSE), vol 5, no. 9, 2018, pp. 1-10 doi: http://dx.doi.org/10.20431/2349-0381.0509001.

Copyright: () 2018 Authors. This is an open-access article distributed under the terms of the Creative Commons Attribution License, which permits unrestricted use, distribution, and reproduction in any medium, provided the original author and source are credited. 